DOI: https://doi.org/10.18371/fp.3(35).2019.190170

УДК 331.5.024.5

\title{
ФОРМУВАННЯ МОЛОДІЖНОГО ПІДПРИЕМНИЦТВА В УКРАЇНІ ТА АНАЛІЗ ФАКТОРІВ ВПЛИВУ НА ЙОГО РОЗВИТОК
}

\section{ПЕТРЕНКО Вікторія Сергї̈вна}

д.е.н., доцент, професор кафедри обліку фінансів, та підприємництва

Херсонський державний університет

e-mail: petrenkovika1986@gmail.com

\section{КАРНАУШЕНКО Алла Сергї̈вна}

к.е.н., асистент кафедри економіки та фінансів

ДВНЗ «Херсонський державний аграрний університет»

e-mail: allakarnaushenko88@gmail.com

Анотація. У статті визначено значення розвитку малого та середнього бізнесу для економіки. Особливе місие в розвитку бізнесу посідає молодіже підприємництво, яке являється важливим елементом формування середнього класу. Виявлено причини незадовільної статистики, щодо формування власної справи серед молоді, а також наведено сильні та слабкі сторони. Знаючи стримуючі фактори було запропоновано основні шляхи стимулювання та активізаиіі розвитку підтримки молодіжного підприємництвв.

Ключові слова: підприємництво, молодіжне підприємництво, молодь, стримуючі фактори, малий та середній бізнес, зайнятість молодi.

Постановка проблеми. В стратегії розвитку України, урядом визначено основні напрями розвитку країни серед яких необхідність модернізації країни, побудова інноваційної економіки та створення підприємницької інфраструктури. На сьогодні тема підприємництва в Україні $\epsilon$ актуальною. На сам перед це пов'язано 3 розвитком малого та середнього бізнесу, а також 3
Аннотация. $B$ cmaтье определено значение развитию малого и среднего бизнеса для экономики. Особое место в развитии бизнеса занимает молодежное предпринимательство, является важным элементом формирования среднего класса. Выявлены причины неудовлетворительной статистики, по формированию собственного дела среди молодежи, а также приведены сильные и слабые стороны. Зная сдерживающие факторы были предложены основные пути стимулирования и активизации развития поддержки молодежного предпринимательства.

Ключевые слова: предпринимательство, молодежное предпринимательство, молодежь, сдерживающие факторы, мальй и средний бизнес, занятость молодежи.

просуванням i популяризацією підприємництва серед молодих людей. Варто відзначити, що розвиток малого i середнього бізнесу дуже важливий як зі сторони створення нових робочих місць, так і з позиції економічних переваг, що дозволяють успішно конкурувати 3 великим бізнесом. До них відносяться: швидка оборотність коштів; економія коштів за рахунок зниження витрат на 
утримання апарату управління; взаємозамінність працівників; гнучкість та вміння швидко перебудовуватися i реагувати на зміну зовнішнього середовища; підвищена схильність до інноваційної діяльності; здатність ризикувати. Особливе місце в економіці країни займає молодіжне підприємництво, так як являється інструментом подолання загальносвітової проблеми - проблеми молодіжного безробіття, яка останнім часом в нашій країні загострилась. Молодь являється головним партнером держави, потенціалом економічного та інноваційного розвитку країни, але емпіричні дослідження вчених свідчать про низьку підприємницьку активність серед молодих людей та невисокий рівень доходів молодих підприємців. Тому потрібно акцентував увагу на виявлення факторів, які впливають на повільний розвиток молодіжного підприєм-ництва та причини низьких прибутків підприємців.

Аналіз останніх досліджень та публікацій. Тема розвитку молодіжного підприємництва, а також виявленням основних переваг та недоліків від здійснення такої діяльності $є$ актуальною серед вітчизняних та зарубіжних науковців. Гросул В.А., Дядюк М.А., Зубков С.О. [1] в своїй роботі досліджували сучасний досвід, проблеми та перспективи розвитку молодіжного підприємництва в Україні. Крім того автори дійшли висновку, що «...молодіжне підприємництво в Україні $є$ джерелом у вирішенні не тільки проблем молоді, а й соціально-економічних державних проблем, що зумовлює необхідність розширення його можливостей і використання наявного потенціалу...». Назаркевич О.Б. [2] у власному дослідженні стверджує, що «...активізація молоді в Україні через формування потужного інституту молодіжного підприємництва $\epsilon$ важливим аспектом підвищення рівня національної безпеки, забезпечення сталого розвитку сільських територій й формування спроможних громад...». Такі вчені як Жданов I., Лібанова Е., Цимбал О., Ярош О., Лісогор Л., Кжаклевська Е., Дмитрук Н., Зарембо К. [3-7] у своїх працях доказали важливість зайняття молодіжним підприємництвом як одним iз способів вирішення проблем зайнятості та зниження безробіття цієї верстви населення.

Аналіз останніх публікацій показав, що на даний момент не вистачає досліджень, які б стосувалися сильних та слабких сторін молодіжного підприємництва, а також виявлення факторів які впливають на його розвиток.

Метою дослідження $\epsilon$ обгрунтування важливості створення підприємництва для молодих людей, а також проаналізувати фактори впливу на розвиток молодіжного підприємництва.

\section{Виклад основного матеріалу.} Вільний розвиток підприємництва $\epsilon$ одним із атрибутів громадянського суспільства, що дає право кожному громадянину власними силами покращувати особистий добробут та добробут своєї сім'ї. Одним із найбільших прагнень сучасної молоді $\epsilon$ досягнення особистої i фінансової свободи, але страх відповідальності, брак коштів і просто невпевненість у собі змушує молодих людей відклада- 
ти у довгий ящик відкриття власної справи [8].

Підприємництво - це економічна діяльність, метою якого є систематичне отримання прибутку. Підприємництво $є$ основною рушійною силою економіки з досвіду зарубіжних країн. Однак якщо проаналізувати статистику, то можна побачити, що Україна займає далеко не лідируючі позиції, в тому числі по рейтингу індексу підприємницького та економічного розвитку, складеного Global Entrepreneurship Monitor Consortium. Що стосується молодіжного підприємництва, то це особлива сфера суспільних відносин, в яку включається як економічна, так і молодіжна політика держави. Українським урядом активно здійснюється підтримка молодіжного підприємництва, але в законодавчому плані дане питання не врегульоване.

Розглядаючи молодіжне підприємництво як суспільне явище, перш за все слід відзначити, що інституційний аспект становлення i розвитку підприємництва зумовлений різними формами, первинною серед яких $\epsilon$ державне регулювання. При цьому як підприємець, так і держава є сторонами контрактної системи - форми договірних відносин держави і бізнесу. Держава визначає організаційно - правову основу підприємництва, порядок заснування, реорганізації і ліквідації підприємницьких організацій, ліцензування діяльності, розв'язування суперечок та ін.

В сучасних умовах молодіжне підприємництво $є$ доволі важливим елементом формування середнього класу, а тому його підтримка має стати основним завданням державної політики. Підтримка молодих людей, їхнє залучення до творчої, активної участі в житті суспільства - це інвестиції в розвиток стратегічних ресурсів держави [9].

Молодіжне підприємництво - це елемент підвищення рівня зайнятості серед молоді та створення нових малих підприємств i додаткових робочих місць. Розвиток молодіжного підприємництва є одним із найважливіших напрямків економічної політики країни. Проте на сьогодні цей процес відбувається дуже повільно. Сектор малого бізнесу в Україні охоплює понад 2,0 млн. суб'єктів малого підприємництва.

Згідно зі статистикою, приблизно 300 млн молодих людей у віці від 18 до 30 років у всьому світі або не мають постійного місця роботи, або взагалі є безробітними. Близько 20\% 3 них мають відмінні здібностями для початку власного бізнесу i, в силу різних причин, тільки 5\% вирішується на це.

Особливістю молоді (громадяни у віці до 34 років) $є$ інноваційність їх мислення, мобільність, швидкість адаптації до нових умов економічної сфери життєдіяльності, наявність сучасних знань, а також можливість швидкого отримання нових знань.

Разом 3 тим, існують основні проблеми, з якими стикаються молоді люди при відкритті власної справи, а саме:

1. відсутність досвіду, тобто вони не знають, як і з чого почати свій бізнес;

2. недолік фінансової бази, навіть при наявності власного проекту вони не мають можливості реалізувати його на практиці; 
3. недостатність освіти, тобто навіть якщо молоді люди мають основи економічних знань, у них відсутні знання саме в сфері підприємництва.

На сьогоднішній день розвиток молодіжного підприємництва стикається 3 низкою характерних проблем:

1. відсутність повноцінної законодавчої бази;

2. слабка розвиненість системи фінансування бізнес-проектів;

3. наявність високих податкових i кредитних ставок;

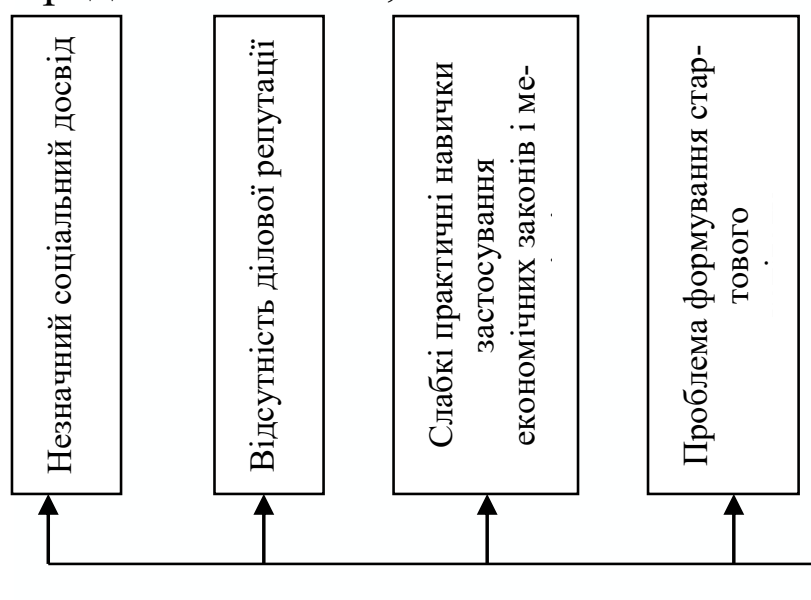

4. відсутність інформаційного ресурсу, в якому молоді люди змогли б знайти необхідну інформацію про існуючі програми підтримки підприємництва;

5. корупційні бар'єри і «тіньова» економіка.

Виділення молодіжного під-приємництва як особливого сегмента підприємництва відбувається тому, що на відміну від інших видів підприємництва воно має свої специфічні ознаки, сильні і слабкі сторони (рис. 1).

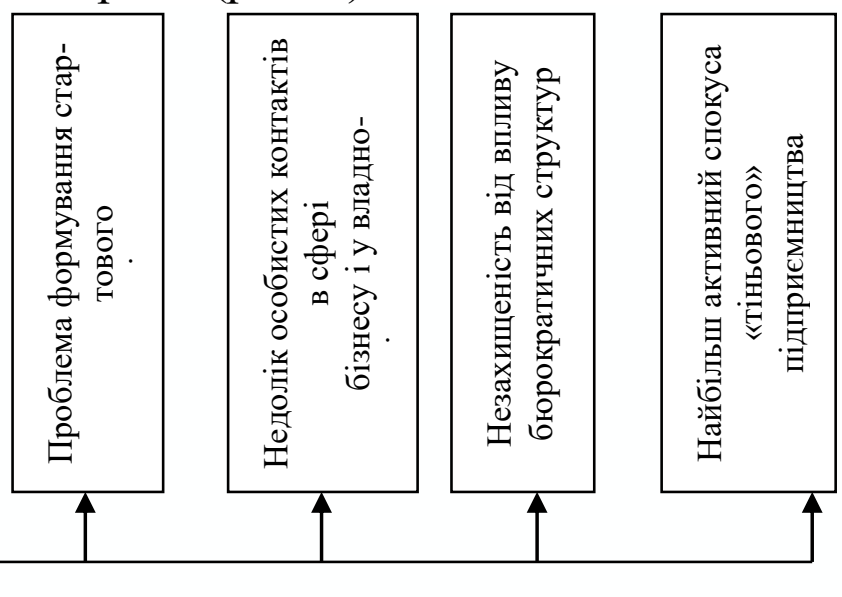

Слабкі сторони молодіжного підприємництва

Сильні сторони молодіжного підприємництва

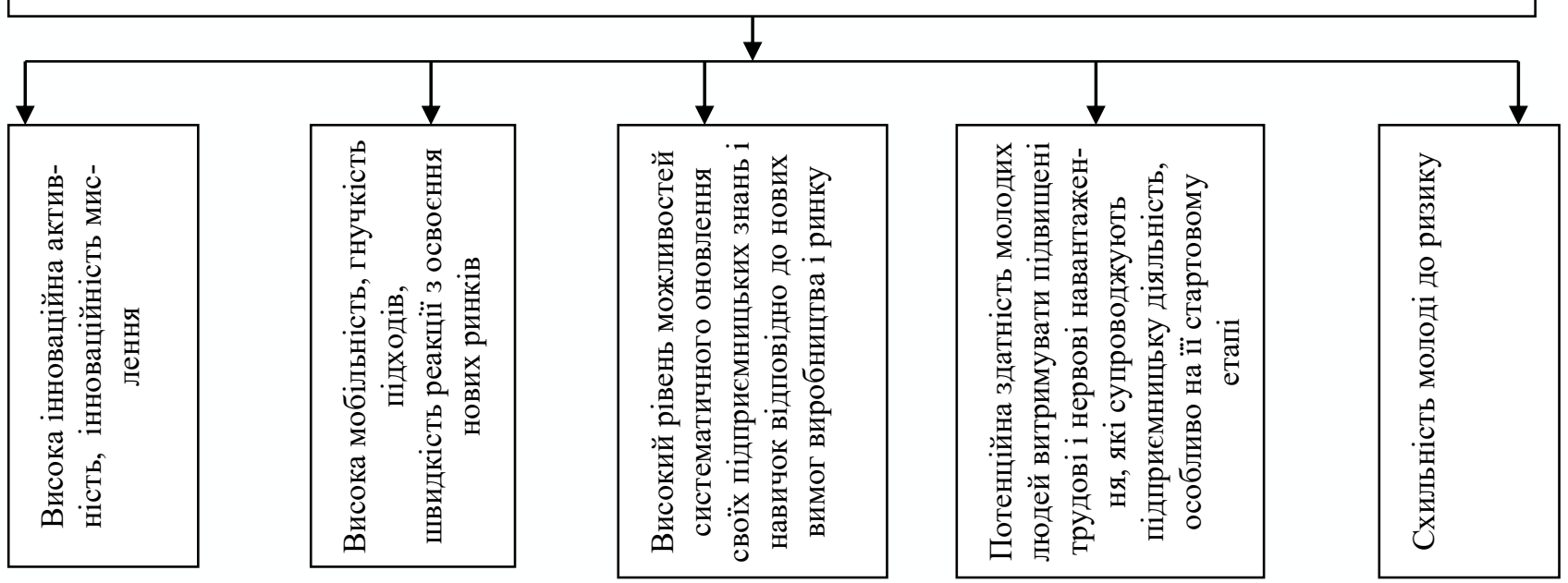

Рис. 1. Сильні та слабкі сторони молодіжного підприємництва 
Вважаємо, що молодіжному підприємництву властиві наступні основні риси:

1. легка адаптація до нових соціально-економічних умов;

2. особлива активність у розвитку приватного сектора економіки (малий і середній бізнес);

3. новаторська сутність;

4. великі можливості перспективних сферах діяльності [12].

Майже 10\% молодих людей віком від 18 до 25 років займаються підприємницькою діяльністю. В Україні діє Закон «Про сприяння соціальному становленню та розвитку молоді в Україні», в якому окремою статтею передбачена державна підтримка підприємницьких ініціатив молодіжного підприємництва загалом. Але суспільно-економічний стан держави не дозволяє повною мірою реалізувати даний закон через відсутність коштів, недосконалість нормативної бази для реалізації положень, задекларованих вищезгаданим законом. Так, реалізація відповідних статей закону щодо пільгового оподаткування молодіжних підприємств могла б надати відчутну фінансову підтримку та організувати роботу щодо здійснення державної молодіжної політики в частині зайнятості та працевлаштування. На практиці не існує розмежування підприємців за віковими категоріями і тим більше достатньої підтримки здійснення підприємництва новим поколінням українських бізнесменів [8].

Згідно проведених опитувань молоді, щодо перспективи зайняття бізнесом, $78 \%$ опитаних молодих людей вважають відкриття власної справи основним способом самореалізації, 60\% респондентів вважають за краще відкрити власний бізнес, ніж працювати за наймом, адже в підприємництві можна розраховувати на отримання високих доходів. Однак сьогодні тільки 3\% молодих людей мають власних бізнес. Тому варто встановити причини затримки розвитку підприємництва в цілому, і молодіжного, зокрема.

Серед факторів впливу, науковці виділяють фактори: зовнішнього середовища (держава, постачальники, кредитори, споживачі) і внутрішнього середовища (власник, менеджери, наймані працівники). Якщо фактори внутрішнього середовища залежать в більшій мірі від власників та топменеджерів підприємства, то спрогнозувати зміни в зовнішньому середовищі дуже складно для малих підприємців. Тому доцільно розглянути лише фактори зовнішнього середовища [14].

Як показує практика, для розвитку малих форм підприємництва необхідна підтримка органів влади на всіх рівнях. Це обумовлено наступними обставинами:

1. нестійкістю доходів через невеликі обсяги виробництва;

2. вразливістю при порушенні договірних зобов'язань;

3. великою залежністю від кредитів, банків та ін.

Успішний розвиток національного молодіжного підприємництва передбачає необхідність врахування таких чинників:

1. Особливості різних вікових груп молоді. Так, підліткова група (молодь 
віком до 19 років) - це, в основному, учні середніх шкіл, ліцеїв, професійних училищ. Питома вага їх серед економічно активної молоді України складає 33\%. Вони переважно не залучені до трудової діяльності. Однак істотне зниження життєвого рівня значної частини населення змінило життєву позицію цієї категорії молоді. Багато 3 них намагаються заробити гроші будь-яким чином, переважно це самозайнятість або праця у неформальному секторі економіки.

2. Перспективні сфери молодіжного підприємництва. Оскільки молодь найшвидше відгукується на нововведення, є менш консервативною, тому дуже важливим сектором молодіжного підприємництва має стати сфера високотехнологічних послуг.

3. Недостатні розміри фінансування активної політики зайнятості. В Україні, на жаль, фінансування заходів, пов'язаних із здійсненням активної політики зайнятості, $€$ недостатHiм.

4. Роль недержавних інститутів у сприянні молодіжному підприємництву. Традиційна політика державної підтримки малих підприємств реалізовується в межах комплексної програми розвитку підприємництва в Україні. Частково (надання методичної допомоги) ці завдання виконувалися б через відділ сприяння підприємницькій діяльності при органах влади.

Для популяризації підприємництва серед молоді, в нашій країні створюються організації та асоціації, які надають допомогу в розвитку молодіжного підприємництва. Крім того урядом створено певне нормативноправове підгрунтя, яке визначає місце молодих підприємців в молодіжній політиці держави. Так, відповідно до розпорядження Кабінету Міністрів України «Про схвалення Концепції Державної цільової соціальної програми «Молодь України» на 2016-2020 роки» одним із шести пріоритетів державної молодіжної політики є безпосередньо збільшення зайнятості молоді через створення власної справи та бізнесу, що досягатиметься в процесі взаємодії та співпраці між органами державної влади та місцевого самоврядування, вітчизняними й міжнародними громадськими об'єднаннями та молодими підприємцями [10].

Підтримка та розвиток молодіжного підприємництва, як з боку державних органів управління, так і міжнародних та громадських організацій, $є$ запорукою підвищення рівня зайнятості серед молоді та створення нових малих підприємств i додаткових робочих місць. Тим паче, що в Україні 42,5 \% молодих людей вважають, що «Бізнесмени» та «Підприємці» відносяться до ТОП-5 професій, що дають можливість досягнути успіху в житті [11].

Крім того, молодим починаючим підприємцям потрібна допомога в навчанні основам бізнесу, надання правової підтримки (беручи до уваги сферу оподаткування та бухгалтерський облік такої діяльності). Як показує досвід розвинених і країн, що розвиваються, без цілеспрямованої підтримки держави сформувати хоча б невеликий шар мікро- та малих підприємців практично неможливо.

Слід активніше розвивати бізнес інкубатори, молодіжні біржі праці, клуби ділового спілкування, консуль- 
таційні клуби, жіночі підприємницькі клуби та ін. Створення i розвиток жіночих клубів буде стимулювати формування різних форм малого підприємництва серед жінок. Звісно, підприємництво не повинно обмежуватися рамками торгівлі, послуг та іншими сферами, в яких характерні швидкі обороти коштів. Воно повинно розвиватися також в сфері нових технологій, інформаційних систем та комунікацій.

Можна виділити основні фактори підтримки розвитку молодіжного підприємництва в нашій країні:

1. створення стабільного законодавства, що служило б основою для вибудовування системи підтримки молодіжного підприємництва;

2. збільшення фінансування бізнеспроектів молодих підприємців;

3. зменшення податкових і кредитних ставок, що було б стимулом для створення власного бізнес-проекту;

4. підтримка в просуванні вироблених суб'єктами молодіжного підприємництва товарів (робіт, послуг) [13].

Крім того, важливо просувати підприємницьку культуру серед молоді - організовувати семінари, тренінг, лекції, круглі столи з питань підприємництва, які будуть проходити у відкритій формі і в яких зможуть взяти участь усі бажаючі, а також:

1. необхідно збільшити ефективність роботи бізнес-інкубаторів;

2. збільшити ступінь інформованості молодих людей про можливості зайнятися підприємництвом (через 3MI);

3. розглянути в рамках податкового законодавства можливості звільнення нових бізнес-проектів від сплати податків і пільгового оподаткування протягом певного часу;

4. передбачити виділення цільових грантів на фінансування бізнеспроектів;

5. удосконалити механізми пільгового кредитування для молодих підприємців;

6. створити орган, який здійснює контроль і оцінку ефективності реалізації різних програм по підтримці молодіжного підприємництва;

7. необхідно створити інформаційний інтернет-ресурс, де можна буде знайти всю необхідну інформацію про існуючі програми підтримки підприємництва і всю необхідну інформацію про те, як почати свій бізнес-проект;

8. створити «гарячу лінію» 3 питань створення та розвитку бізнесу для молодих людей;

9. ввести в школах та інших учбових закладах предмет «Підприємництво».

Висновки. Таким чином, вище зазначені пропозиції дозволять вирішити багато проблем в сфері зайнятості молодих людей, сформують необхідні умови для самоорганізації і стимулювання активності молоді в сфері підприємництва.

В цілому, саме молодь на сьогоднішній день являє собою ту основу, на яку повинна спиратися економіка, а без наявності твердої основи розвиток всієї країни неможливий.

В Україні тема підприємництва залишається актуальною. Це пов'язано 3 розвитком малого і середнього бізнесу, а також зі збільшенням частки середнього класу в суспільстві. Все- 
світній банк зі своїх досліджень вста- запланованого економічного ефекту. новив, що якщо в країні на малий і се- Саме це ще раз доводить важливість редній бізнес припадає менше $40 \%$ ВВП, то інвестиції в економіку цієї нейтралізації стримуючих причин розвитку малого і середнього бізнесу. країни не призведуть до необхідного,

\section{Список використаної літератури}

1. Гросул В.А., Дядюк М.А., Зубков С.О. Сучасний досвід, проблеми та перспективи розвитку молодіжного підприємництва в Україні. Збірник Наукових прац̧ь ХДУХТ. 2018. Вип. 27. с. 66-82. URL: http://elib.hduht.edu.ua/bitstream/123456789/2768/1/\%d0\%93\%d1\%80\%d0\%be\%d1 $\% 81 \% \mathrm{~d} 1 \% 83 \% \mathrm{~d} 0 \% \mathrm{bb} \% 2 \mathrm{c} \% 20 \% \mathrm{~d} 0 \% 94 \% \mathrm{~d} 1 \% 8 \mathrm{f} \% \mathrm{~d} 0 \% \mathrm{~b} 4 \% \mathrm{~d} 1 \% 8 \mathrm{e} \% \mathrm{~d} 0 \%$ ba $\% 2 \mathrm{c} \% 2$ 0\%d0\%97\%d1\%83\%d0\%b1\%d0\%ba\%d0\%be\%d0\%b2\%d0\%b0.pdf (дата звернення: 06.09.2019).

2. Назаркевич О.Б. Концептуалізація інклюзивної моделі ефективного використання потенціалу молодіжного підприємництва в регіонах України. Економіко - управлінські аспекти трансформації та інновачійного розвитку галузевих і регіональних суспільних систем в сучасних умовах : Матеріали Всеукраїнської науково-практичної конференції. URL: http://194.44.112. 14/bitstream/123456789/7173/1/6774p.pdf (дата звернення: 06.09.2019).

3. Формування та реалізація державної молодіжної політики в Україні в умовах децентралізації / I. О. Жданов та ін. Тернопіль : ТОВ «Тернограф», 2017. $100 \mathrm{c}$.

4. Лібанова Е., Цимбал О., Ярош О., Лісогор Л. Перехід на ринок праці молоді України : результати міжнародного дослідження «School-to-work transition surveys» в Україні у 2013 та 2015 роках. Міжнародне бюро праці. Женева : MOП, 2016. URL: http://www.ilo.org/wcmsp5/groups/public/--ed_emp/documents/publication/wcms_536293.pdf (дата звернення: 06.09.2019).

5. Кжаклевска Е., Вільямсон Г. Молодіжна політика в Україні. Висновки Команди міжнародних оглядачів Ради Свропи. Страсбург : Видавництво Ради Європи, 2013. 192 с.

6. Молодь України - 2017 : результати соціологічного дослідження. / Н. Дмитрук та ін.. Тернопіль: ТОВ «Терно-граф», 2017. 72 с. URL: 
http://www.dsmsu.gov.ua/media/2017/11/16/7/ Socdoslidjennya_2017.pdf (дата звернення: 06.09.2019).

7. Українське покоління Z: цінності та орієнтири. Результати соціологічного дослідження / К. Зарембо та ін..Київ : Фонд ім. Фрідріха Еберта, 2017. 136 с. URL: https://zaxid.net/resources/newsfiles/319940_Ukr_Generation_ukr_inet-1.pdf (дата звернення: 06.09.2019).

8. Молодіжне підприємництво - перспективний шанс для молодих спеціалістів. ALLREF: веб-сайт. URL: https://allref.com.ua /uk/skachaty/Molodijne_pidpriyemnictvo_-_perspektivniiy_shans_dlya_molodihspe cia listiv (дата звернення: 06.09.2019).

9. Думанська І.Ю. Молодіжне інноваційне підприємництво як національна доктрина модернізації економіки. Вісник Хмельнищького національного універcumemy. 2013. №4. T.2. с. 194 - 201. URL: http://elar.khnu.km.ua/jspui/bitstream/123456789/1157/1/DUMANSKA.pdf (дата звернення: 06.09.2019).

10. Мерзляк А., Боярін Є. Механізм державної підтримки само зайнятості молоді: вітчизняна практика та зарубіжний досвід. Державне управління та місцеве самоврядування. 2016. Вип. 4 (31). с. 73-80. URL: http://www.dridu.dp.ua/vidavnictvo/2016/2016_04(31)/13.pdf (дата звернення: 06.09.2019).

11. Романенко I. Молодіжне підприємництво - реалії та перспективи. Національна платформа малого та середнього бізнесу : веб-сайт. URL: https://platforma-msb.org/molodizhne-pidpryyemnytstvo-realiyi-ta-perspektyvy/ (дата звернення: 06.09.2019).

12. Стефанишин О.В. «Нова економіка» і молодіжне підприємництво. Наукові записки. 2001. №4. с. 41-43 URL: http://nz.uad.lviv.ua/static/media/4/15.pdf (дата звернення: 06.09.2019).

13. Танклевська Н.С., Карнаушенко А.С. Розвиток фінансування інноваційної діяльності сільськогосподарських підприємств: монографія. Херсон: Айлант, 2015. 184 с.

14. Petrenko V., Karnaushenko A. Joint enterprises in foreign trade activity of Ukraine. Baltic Journal of Economic Studies. 2017. T.3. №5. c. 203-207 